\title{
Distribution of Virus Symptoms and Viruses Infecting Field-Grown Cucurbit Crops Under Natural Tropical Conditions Within a Humid Rainforest Transition Agro-Ecology in Nigeria
}

\author{
E.I. Ayo-John', O.O. Odedara ${ }^{2}$, E.V. Loko', F.D. Aworinde', A.C. \\ Tella', I. G. Ogundare', A.M. Kelani', J.O. Hassan', J.O. \\ Oladokun', and O. B. Afolayan ${ }^{1}$ \\ ${ }^{1}$ Department of Crop Protection, and ${ }^{2}$ Department of Microbiology, Federal \\ University of Agriculture, PMB 2240, Abeokuta Ogun State, Nigeria
}

\section{ABSTRACT}

Farmers' fields where cucurbit crops were grown in seven Local Government Areas LGA) of Ogun state were surveyed in 2009 and 2010 for incidence and severity of virus symptoms and the identity of the viruses infecting the crops were determined using DAS-ELISA. Six viruses including Zucchini yellow mosaic virus (ZYMV), Watermelon mosaic virus (WMV), Papaya ringspot virus (PRSV), Cucumber green mottle mosaic virus (CGMMV), Cucumber mosaic virus (CMV), and Melon necrotic spot virus (MNSV) were indexed for in the leaf samples. A total of 14 farms were visited and 130 leaf samples were collected. The incidences of virus symptoms on the field were between 41.0 and $100.0 \%$ while the mean severity score were between 1 (apparently healthy) and 5 (severe symptoms and death) in some locations. The incidences of virus symptoms such as mottle, chlorosis and yellowing, mosaic, leaf distortion, puckering, vein banding and vein clearing were 20.0, 19.2, 18.5, 16.2, $11.5,3.1$ and $3.1 \%$, respectively in the collected leaf samples. However, $8.5 \%$ of the leaf samples were apparently healthy. Serological analysis of the leaf sample showed the presence of ZYMV, PRSV, WMV, CMV, MNSV, and CGMMV. The most widely distributed virus was MNSV which occurred in 9 out of $14(64.3 \%)$ of the locations. This was followed by WMV and CGMMV occurring in 8 out of 14 $(57.0 \%)$ of the locations. PRSV and CMV occurred in $50.0 \%$ of the locations. ZYMV occurred in 5 out of 14 (35.7\%) of the locations. The viruses detected are among the viruses reported to limit the production of cucurbit crops world-wide.

Keywords: pumpkin, cucurbits, virus disease, survey watermelon, cucumber

\section{INTRODUCTION}

Cucurbit crops are important vegetable crops, world-wide especially in developing countries (Bananej and Vardat, 2008). Some of the major cultivated cucurbit crops in Nigeria include Melon (Citrullus colocynthis), cucumber (Cucumis sativus), watermelon (Citrullus lanatus), and fluted pumpkin (Telfairia occidentalis). They are cultivated in open fields under rainfed conditions. Cucumber fruit is 
eaten raw or as salad with other vegetables. The fruit contains about $95-98 \%$ water, about 2.2 carbohydrates, and vitamins (Rassolov, 2000). A fruit of watermelon contains $6 \%$ sugar, $92 \%$ water by weight, and is a good source of vitamins A, B, and C. It also contains lycopene (Maynard, 2001; Levitin and Mrnahoii, 2003). The sugar content and sweetness are the critical factors in determining the quality of many watermelon cultivars (Harlair, 1999). It is used as fresh salad, dessert, pies, vegetable entries, snacks, food, and ornamental decoration (Hamish, 2005).

The southeastern part of Nigeria is rich in both cultivated and wild cucurbit species. They are cultivated for their leaves, fruits, and seeds (Egun, 2007). Pumpkin (Telfairia occidentalis) is a common homestead garden crop in southern Nigeria, and it is mostly cultivated by women (Akoroda, 1990). The crop is mainly cultivated for its succulent young leaves and shoots which are largely used as vegetables. Pumpkin leaves are rich in iron (Fe); the oil seed possesses lactation promoting properties and are widely consumed by nursing mothers (Balogun et al., 2006; Olaniyi and Odedere, 2009).

Farmers in Nigeria grow these crops commercially for consumption to improve nutrition, contribute to food security as well as increase revenue of the producers/farmers, and create employment opportunities thereby improving on the efficiency of utilization of labour (Musmade and Desai, 2001).

Diseases are the main problems in the production of cucurbit plants; more than 200 diseases on cucurbit plants cause serious losses in terms of yield and quality (Yardimci and Korkmaz, 2004).

Viral diseases are more serious for cucurbitaceous plants compared to diseases caused by other agents. Symptoms of viral infections on cucurbitaceae are mosaic, yellowing, stunting, chlorosis, and leaf and fruit deformations (Yardimci and Korkmaz, 2004).

About 35 viruses have been reported to infect cucurbits world-wide. Many virus infections of some of these cucurbits are wide-spread but still largely unreported in Nigeria. The previous reports of cucurbit viruses in Nigeria were Watermelon mosaic virus isolated from C. edulis (C. manni) (Igwegbe, 1983), Telfairia mosaic virus (TeMV) reported on T. occidentalis (Shoyinka et al., 1987) and a strain of PRSV from Cucumis sativus (Owolade et al., 2008) which are the potyviruses that have been reported naturally infecting cucurbits in Nigeria (Owolabi et al., 2012).

In Nigeria cucurbit vegetables are economic cash crops and many farmers suffer losses due to pest and disease problems on the field. Despite the importance of cucurbit crops, information at the local level on the incidence and severity of viral diseases and the identity of viruses that affect them is still scanty. It is important to assess the crops for virus diseases that limit their production in areas where the crop is widely grown. This is an important step towards the development of effective management strategies. Hence this study was undertaken to determine the incidence and distribution of viruses affecting field-grown cucurbits in Ogun state in southwestern Nigeria where cucurbit crops are now widely grown for food and commercial purposes. 


\section{MATERIALS AND METHODS}

\section{Survey for Infected Cucurbit Crops}

Farmer fields and home gardens of cucurbit crops were examined for viruslike symptoms such as mosaic, necrosis, yellowing, vein clearing, vein banding, leaf reduction, leaf distortion, puckering, crinkling, etc. Leaf samples were collected from fluted pumpkin, watermelon, and cucumber plants. The fields were inspected visually and leaf samples were collected in each farm from a mapped out $4 \mathrm{~m}$ by 4 $\mathrm{m}$ sub plots. Ten leaf samples were collected from each farm for virus indexing. The leaf samples were placed in labeled sample bags and preserved in a cooler with ice while in transit. The samples were taken to the laboratory for virus indexing using enzyme linked immune-sorbent assay (ELISA).

The virus disease severities were rated on 10 plants within the sub-plots using a modification of the scale developed by Hassan and Al-masri (1991) where: 1 - No symptom, 2 - Mild symptom (10\% of leaves), 3 - Moderate symptom (10-30\%), 4 Severe symptom (30-50\%), 5 - Leaf distortion and death (over $75 \%$ ).

\section{Indexing for Viruses in Cucurbit Leaf Samples Using DAS-ELISA}

Six viruses including Zucchini yellow mosaic virus (ZYMV), Water melon mosaic virus (WMV), Papaya ringspot virus (PRSV), Cucumber green mottle mosaic virus (CGMMV), Cucumber mosaic virus (CMV), and Melon necrotic spot virus (MNSV) were indexed for using DAS-ELISA as described by Clark and Adams (1977) with specific polyclonal antibodies and produced in Deutsche Sammlung von Mikroorganismen und Zellkulturen GmbH (DSMZ), Germany. For each location two leaf samples were bulked as one before homogenizing $(1: 10 \mathrm{w} / \mathrm{v})$ in extraction buffer $\left(8.0 \mathrm{~g} \mathrm{NaCl}, 0.2 \mathrm{~g} \mathrm{KH}_{2} \mathrm{PO}_{4} 1.1 \mathrm{~g} \mathrm{Na}_{2} \mathrm{HPO}_{4}, 0.2 \mathrm{~g} \mathrm{KCl} / \mathrm{L}, \mathrm{pH}\right.$ 7.4) containing $0.05 \% \mathrm{v} / \mathrm{v}$ Tween 20, and 2\% w/v polyvinylpyrrolidone (Sigma PVP-40). The ELISA plates were coated with one of CGMMV, CMV, WMV, PRSV, and MNSV $1 \mathrm{gG}$ diluted according to manufacturer's specification in coating buffer $(1.59 \mathrm{~g}$ $\mathrm{Na}_{2} \mathrm{CO}_{3}, 2.93 \mathrm{~g} \mathrm{NaHCO}_{3} \mathrm{pH}$ 9.6) into each well of the ELISA plates respectively and incubated at $37^{\circ} \mathrm{C}$ for 2 hours. The plates were washed three times at three minutes interval with washing buffer (PBS-T) from a wash bottle. Using a pipette, $100 \mu \mathrm{l}$ of the sap were pipetted into each well and incubated overnight at $4^{0} \mathrm{C}$. The plates were decanted and washed as earlier described before adding $100 \mu \mathrm{IgG}$ alkaline phosphatase specific for the different viruses respectively diluted as recommended by the manufacturers in conjugate buffer (PBS-T, 2\% PVP and $0.2 \%$ egg albumen (Agdia, U.S.A.) into the wells of the plates and incubated at $37^{\circ} \mathrm{C}$ for 2 hours. The plates were washed as described before addition of $200 \mu \mathrm{l}$ of $1 \mathrm{mg} / \mathrm{ml}$ P-nitro phenyl phosphate (PNP) in substrate buffer (Agdia, U.S.A). The plates were incubated at room temperature for 60 minutes to obtain clear reactions and the absorbance of the well contents read with Mindray MR-96, China at $405 \mathrm{~nm}$. The samples with positive reaction to CGMMV, CMV, WMV, PRSV, MNSV, and ZYMV were observed when the absorbance value at $405 \mathrm{~nm}$ doubled that of the healthy control samples. 


\section{RESULTS}

This work is the first extensive survey in Ogun State to determine the distribution of virus symptoms and viruses infecting field-grown cucurbit crops. Cucurbit crops such as Pumpkin, watermelon, and cucumber were surveyed for virus diseases in seven local government areas of Ogun State namely: Remo North, Obafemi Owode, Odeda, Ifo, Ikenne, Sagamu, and Yewa North in 2009 and 2010 (Table 1). The plants were mostly at their vegetative stage of growth at the time of virus survey. In each location, a maximum of 10 leaf samples showing virus-like symptoms or apparently healthy leaf tissues were collected. The incidences of virus symptoms on the field were between 41.3 and $100.0 \%$ (Table 1). The mean severity score were between 1 (apparently healthy) in one location to 5 (severe symptoms and eventual death) in some locations. Lack of virus control and continuous cropping may have led to build-up of virus inocula; this could have been responsible for the high virus disease incidences in some of the areas surveyed.

\section{Incidence of Virus Symptoms on Cucurbit Crops}

A total of 14 farms were visited and 130 leaf samples were collected. Many farmers did not recognize virus symptoms as being due to disease. The poor knowledge of farmers on virus symptoms and diseases they cause may be the reason for little or no sanitary or control measures undertaken. The incidences of virus symptoms such as mottle, chlorosis and yellowing, mosaic, leaf deformation, puckering, vein banding, and vein clearing in the collected leaf samples were 20.0, $19.2,18.5,16.2,11.5,3.1$, and $3.1 \%$, respectively. However, $8.5 \%$ of the leaf samples were apparently healthy.

The major cucurbit crop encountered was T. occidentalis which accounted for 90 out of $130(69.2 \%)$ of the leaf samples. The most frequently observed virus symptoms observed on the crop were mottle, chlorosis and yellowing, mosaic, leaf distortion, puckering, vein banding, and vein clearing which accounted for 26.7, $25.5,16.7,15.6,6.7,5.5$, and $2.2 \%$, respectively (Figure 1 ). A total of $1.1 \%$ of the leaf samples were apparently healthy. The watermelon plants were 20 out of 130 $(15.4 \%)$. The major virus symptoms on watermelon were mosaic, followed by chlorosis + yellowing, leaf distortion, and vein clearing. The cucumber plants were at the seedling stage when they were about three weeks old and when $50.0 \%$ of the leaf samples appeared apparently healthy. The second cucumber farm had fruited and the leaves had nearly dried up at the time of survey. The major symptoms observed were chlorosis and yellowing, leaf distortion (Figure 1). The increase in cucurbit production in southwest Nigeria and the susceptibility of the cultivars grown to virus infection as observed in the field can lead to yield losses and/or malformed fruits which attract low market value.

\section{Distribution of Virus Symptoms in Surveyed Locations}

Virus symptoms were observed in all the locations surveyed, although the symptoms varied in the different locations. In Ifo where 34 leaf samples were collected, the major symptoms were mosaic (29.4\%), chlorosis + yellowing 
(20.6\%) and leaf distortion (17.6\%). In Obafemi Owode, Odeda and Yewa North Local Government Areas (LGA) where 20 leaf samples each were collected, the cucurbit crops in Obafemi Owode had the highest incidence of virus symptoms to be mottle $(35.0 \%)$ while for Odeda it was puckering symptoms $(45.0 \%)$ and Yewa North mosaic and chlorosis + yellowing symptoms $15.0 \%$ each, respectively, although $50.0 \%$ of the leaf samples were symptomless.

Table 1. Incidence and severity of virus symptoms on field-grown cucurbit crops in Ogun State in 2009 and 2010.

\begin{tabular}{|c|c|c|c|c|c|c|c|c|}
\hline Location & Crop & $\begin{array}{l}\text { Stage of } \\
\text { plant } \\
\text { growth }\end{array}$ & $\begin{array}{l}\text { No. of } \\
\text { farms }\end{array}$ & $\begin{array}{l}\text { No. of } \\
\text { plants in } \\
\text { Sub plot }\end{array}$ & $\begin{array}{c}\text { No. } \\
\text { infected }\end{array}$ & $\begin{array}{c}\% \\
\text { incidence }\end{array}$ & $\begin{array}{c}\text { Disease } \\
\text { severity } \\
\text { score }\end{array}$ & $\begin{array}{c}\text { Major } \\
\text { symptoms }\end{array}$ \\
\hline $\begin{array}{l}\text { Remo } \\
\text { North }\end{array}$ & $\begin{array}{c}T . \\
\text { occidentalis }\end{array}$ & Vegetative & 1 & nt & $*_{\text {nt }}$ & nt & 5 & $\begin{array}{c}\text { Mottle, } \\
\text { mosaic } \\
\text { puckering }\end{array}$ \\
\hline $\begin{array}{l}\text { Obafemi } \\
\text { Owode }\end{array}$ & $\begin{array}{c}T . \\
\text { occidentalis }\end{array}$ & Vegetative & 1 & nt & nt & nt & 4 & $\begin{array}{c}\text { Mottle, } \\
\text { mosaic } \\
\text { puckering }\end{array}$ \\
\hline Odeda & $\begin{array}{c}T . \\
\text { occidentalis }\end{array}$ & Vegetative & 1 & 20 & 10 & 50.0 & 3 & $\begin{array}{l}\text { Yellowing, } \\
\text { chlorotic } \\
\text { spots, leaf } \\
\text { distortion }\end{array}$ \\
\hline Odeda & $\begin{array}{c}T . \\
\text { occidentalis }\end{array}$ & Vegetative & 1 & 20 & 10 & 50.00 & 3 & " \\
\hline Shagamu & $\begin{array}{c}T . \\
\text { occidentalis }\end{array}$ & Vegetative & 1 & 20 & 20 & 100.00 & 3 & $\begin{array}{c}\text { Mosaic, leaf } \\
\text { distortion }\end{array}$ \\
\hline & $\begin{array}{c}\mathrm{T} . \\
\text { occidentalis }\end{array}$ & Vegetative & 1 & nt & nt & $\mathrm{nt}$ & 2 & $\begin{array}{l}\text { Mosaic, } \\
\text { mottle }\end{array}$ \\
\hline Ifo & $\begin{array}{c}C . \\
\text { lanatus }\end{array}$ & fruiting & 1 & 14 & 14 & 100.0 & 4 & $\begin{array}{c}\text { Mottle, leaf } \\
\text { distortion }\end{array}$ \\
\hline Yewa North & $\begin{array}{c}C . \\
\text { lanatus }\end{array}$ & fruiting & 1 & 20 & 18 & 90.0 & 3 & $\begin{array}{c}\text { Mottle, leaf } \\
\text { distortion }\end{array}$ \\
\hline Yewa North & C. sativus & seedling & 1 & 20 & 0 & 0.0 & 1 & none \\
\hline Ifo & C. sativus & Harvest & 1 & 10 & 8 & 80.0 & 5 & $\begin{array}{c}\text { Leaf } \\
\text { distortion }\end{array}$ \\
\hline Ikenne & C. sativus & Harvest & 1 & 10 & 6 & 60.0 & 4 & chlorosis \\
\hline Ifo & $\begin{array}{c}T . \\
\text { occidentalis }\end{array}$ & Vegetative & 1 & 17 & 11 & 64.7 & 4 & $\begin{array}{l}\text { Mosaic, } \\
\text { chlorosis } \\
\text { Mottle. }\end{array}$ \\
\hline $\begin{array}{l}\text { Obafemi } \\
\text { Owode }\end{array}$ & $\begin{array}{c}T . \\
\text { occidentalis }\end{array}$ & Vegetative & 1 & 25 & 11 & 44.0 & 4 & $\begin{array}{c}\text { Chlorosis, } \\
\text { leaf } \\
\text { distortion }\end{array}$ \\
\hline Ikenne & $\begin{array}{c}T . \\
\text { occidentalis }\end{array}$ & Vegetative & 1 & 58 & 24 & 41.3 & 3 & $\begin{array}{c}\text { Mottle, leaf } \\
\text { distortion }\end{array}$ \\
\hline
\end{tabular}

\footnotetext{
$*_{\mathrm{nt}}=$ not test
}

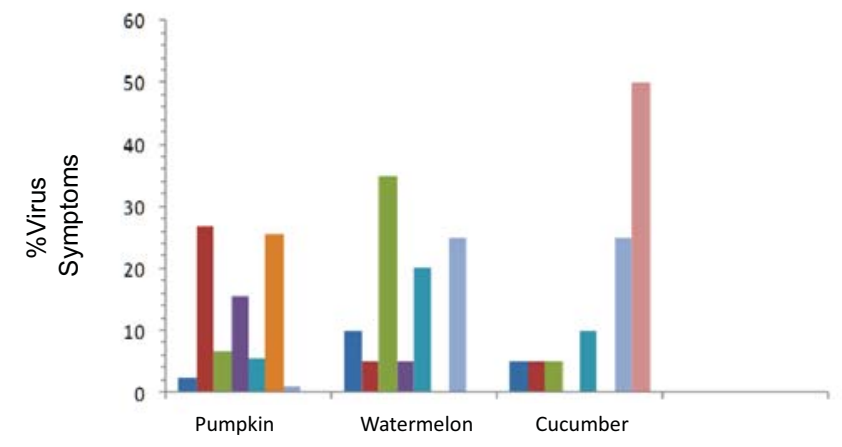

"vein clearing

= Mottle

Mosaic

w Puckering

= leaf deformation

= Vein banding

=chlorosis yellowing

"Healthy

Figure1. Distribution of virus symptoms observed on cucurbit crops in Ogun State in 2009 and 2010. 


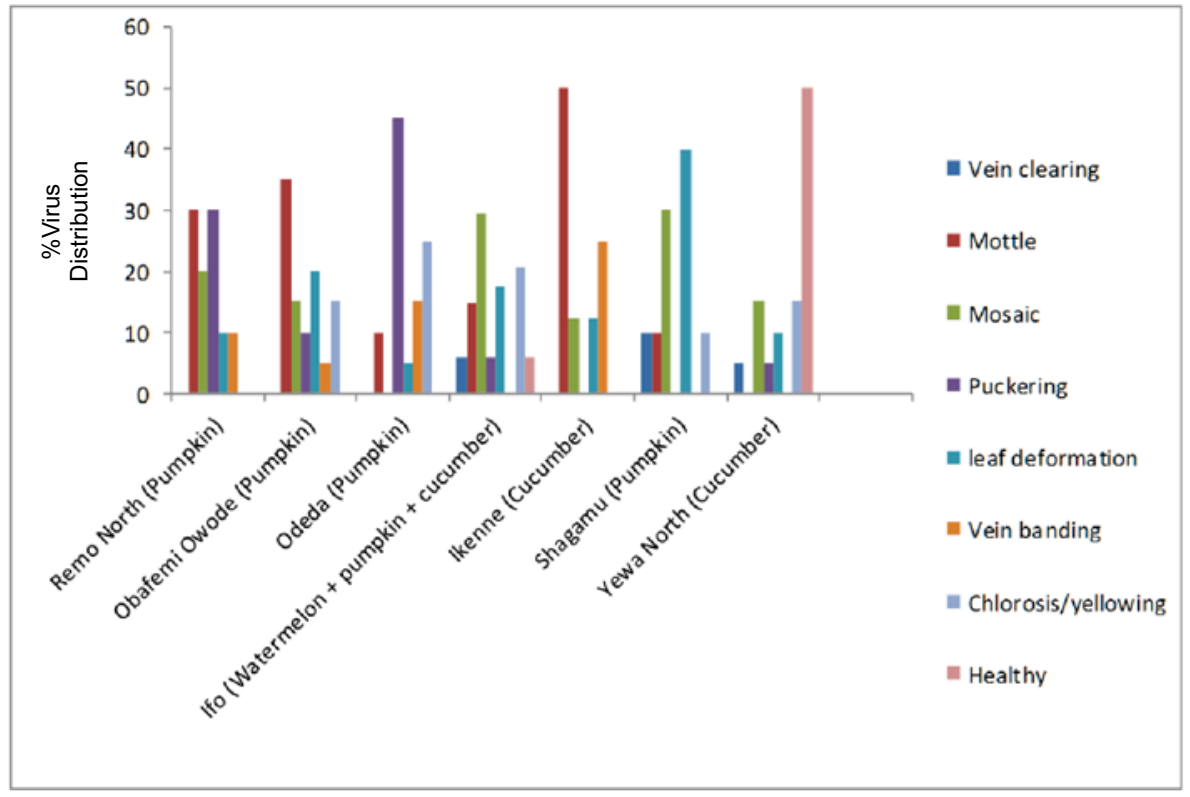

Figure 2. Distribution of virus symptoms in 2009 and 2010 for cucurbit virus disease.

In Remo North and Sagamu where 10 leaf samples were picked each, symptoms of mosaic and puckering were most prominent $(30.0 \%$ each respectively) and for Sagamu, it was leaf distortion followed by mosaic accounting for 40.0 and $30.0 \%$ of the leaf samples, respectively (Figure 2). Some factors that appear to favor the spread of virus diseases are virus symptoms not being recognized by many farmers and the transmission by aphid vectors. The widespread distribution of virus diseases could be due to exchange of planting materials among farmers and/or use of previous season's seeds for new plantings.

\section{Detection and Distribution of Viruses Infecting Cucurbit Crops}

In our current survey of Ogun State, all the 6 viruses indexed were present in the cucurbit growing areas surveyed. Serological analysis of the leaf sample revealed the presence of ZYMV, PRSV, WMV, CMV, MNSV, and CGMMV. The most widely distributed virus was MNSV which occurred in 9 out of 14 (64.3\%) of the locations. This was followed by WMV and CGMMV occurring in 8 out of 14 $(57.0 \%)$ of the locations. PRSV and CMV occurred in $50.0 \%$ of the locations. The virus with the least distribution was ZYMV which occurred in 5 out of $14(35.7 \%)$ of the locations (Table 2).

Viruses have been a major cause of quantity and quality reduction in commercial cucurbit crops worldwide (Provvidenti, 1996). A previous survey on viruses infecting T. occidentalis in Imo State Nigeria was in 2007 and the viruses reported were TeMV,ZYMV, and CMV (Oben et al., 2007).

The occurrence of viruses in the crops surveyed has shown that the cultivars were susceptible to virus infection. Virus symptoms observed on the field were similar to those reported on cucurbit crops by Ali et al., (2004). The most widely distributed virus was MNSV. The virus is soil borne and the transmission can occur with the use of contaminated tools. 
MNSV causes severe symptoms and yield loss in melon (Sug-ju et al., 2007). The virus can also be transmitted through seed. A common practice among farmers in the southwest of Nigeria is the use of seeds from previous season's harvest for new planting. If such seeds were obtained from infected plants, this could lead to infected seedlings that would serve as sources of primary inoculum in the field. The two other viruses widely distributed were WMV and CGMMV. WMV is aphid transmitted and its host-range includes other non-cucurbit crop where the virus can survive between growing seasons. Eradication of weeds and alternate host can help reduce the incidence of the virus. CGMMV also causes economically important disease of cucurbits. The vector is yet unknown and aphids do not transmit the virus. The transmission is through mechanical means such as foliage contact, soil contamination, through infected seed, and handling of plants. It is important to avoid infection with CGMMV because it can cause yield reduction of about $25 \%$ or more if no control measure is undertaken (Rao and Varma 1984). PRSV, CMV and ZYMV are aphid transmitted and cause serious diseases on cucurbit crops. Favorable weather conditions for vector populations make aphid transmitted diseases one of the most important problems for growers. The avoidance of aphids responsible for transmitting these viruses should be a primary component of management strategy. Various management strategies should be employed to reduce virus infections on cucurbit crops. The most important strategy for control of virus diseases would include proper land cultivation to eliminate volunteer plants that harbor the virus, effective weed control, and or development of resistant varieties. For the seed and soil-borne MNSV soil disinfection and clean seeds may be used where available.

Table 2. Serological detection of viruses in cucurbit leaf samples collected in 2009 and 2010 in Ogun state.

\begin{tabular}{|c|c|c|c|c|c|c|c|c|c|}
\hline Location & Crop & $\begin{array}{c}\text { Year } \\
\text { of } \\
\text { survey }\end{array}$ & $\begin{array}{l}\text { No. } \\
\text { tested }\end{array}$ & ZYMV & PRSV & WMV & CMV & MNSV & CGMMV \\
\hline Remo & $T$ & July & 5 & $++++*$ & ++++ & ++++ & - & +++++ & + \\
\hline North & occidentalis & 2009 & & & & & & & \\
\hline Obafemi & T. & July & 5 & +++ & + & +++ & - & + & - \\
\hline Owode & occidentalis & 2009 & & & & & & & \\
\hline Odeda & $\begin{array}{c}T . \\
\text { occidentalis }\end{array}$ & $\begin{array}{l}\text { July } \\
2009\end{array}$ & 5 & +++ & - & + & - & - & - \\
\hline Odeda & $\begin{array}{c}T . \\
\text { occidentalis }\end{array}$ & $\begin{array}{l}\text { July } \\
2009\end{array}$ & 5 & + & - & + & ++ & - & - \\
\hline Shagamu & $\begin{array}{c}T . \\
\text { occidentalis }\end{array}$ & $\begin{array}{l}\text { July } \\
2009\end{array}$ & 5 & +++++ & +++++ & +++++ & +++++ & ++++ & + \\
\hline Ifo & $\begin{array}{l}\text { T. } \\
\text { occidentalis }\end{array}$ & $\begin{array}{l}\text { July } \\
2009\end{array}$ & 5 & +++++ & +++ & +++ & +++++ & +++ & + \\
\hline Ifo & $\begin{array}{c}C . \\
\text { lanatus }\end{array}$ & $\begin{array}{c}\text { August } \\
2010\end{array}$ & 5 & + & +++++ & +++++ & ++++ & ++++ & + \\
\hline $\begin{array}{l}\text { Yewa } \\
\text { North }\end{array}$ & $\begin{array}{c}\text { C. } \\
\text { lanatus }\end{array}$ & $\begin{array}{c}\text { August } \\
2010\end{array}$ & 5 & + & +++++ & +++++ & +++ & +++ & ++++ \\
\hline $\begin{array}{l}\text { Yewa } \\
\text { North }\end{array}$ & C. sativus & $\begin{array}{c}\text { August } \\
2010\end{array}$ & 5 & - & - & - & - & + & - \\
\hline Ifo & C. sativus & $\begin{array}{c}\text { August } \\
2010\end{array}$ & 2 & - & - & - & - & - & - \\
\hline Ikenne & C. sativus & $\begin{array}{c}\text { August } \\
2010\end{array}$ & 3 & - & - & - & + & + & + \\
\hline Ifo & $\begin{array}{c}T . \\
\text { occidentalis }\end{array}$ & $\begin{array}{c}\text { August } \\
2010\end{array}$ & 5 & - & - & - & - & - & + \\
\hline $\begin{array}{c}\text { Obafemi } \\
\text { Owode }\end{array}$ & $\begin{array}{c}T . \\
\text { occidentalis }\end{array}$ & $\begin{array}{c}\text { August } \\
2010\end{array}$ & 5 & - & - & - & - & - & ++ \\
\hline Ikenne & $\begin{array}{c}T . \\
\text { occidentalis }\end{array}$ & $\begin{array}{c}\text { August } \\
2010\end{array}$ & 5 & - & + & - & +++ & + & - \\
\hline Total & & & 65 & & & & & & \\
\hline
\end{tabular}

$+=1$ out of $5,++=2$ out of $5,+++=3$ out of $5,++++=4$ out of 5 and $+++++=5$ out of 5 leaf samples tested that reacted with the specific polyclonal antibody. 


\section{REFERENCES}

AKORODA M.O. 1990. Ethnobotany of T. occidentalis among Igbos of Nigeria. Economic Botany 44 (1): 29-39.

ALI A., T. NATSUAKI, and S. OKUDA 2004. Identification and Molecular Characterisation of Viruses Infecting Cucurbits in Pakistan. J. Pathology 152, 677-682.

AJIBADE, S.A., M.O. BALOGUN, O.O. AFOLABI and M.D. KUPOLATI 2006. Sex differences in biochemical components of telfairia occidentalis Hook F. Journal of Food, Agriculture and Environment 4 (1) 155-156.

BANANEJ K. and A. VAHDAT (2008). Identification, distribution and incidences of viruses in field-grown cucurbit crops in Iran. Phytopathol. Meditter. 44: 247-257

CLARK M.F. and A.N. ADAMS 1977. Characteristics of the micro plate method of enzyme- link immunosorbent assay for detection of plant viruses. Journal of General Virology 34: 475-480.

EGUN A.C. 2007. Comparative Marketable Leaf Yield of Staked and Unstaked Pumpkin (Telferia occidentalis) in a Tropical Ultisols. Journal of Community Science 1(1): $27-29$.

HAMISH R. 2005. Citrullus lanatus (Watermelon Tsamma). Museums Online South Africa.

HARLAIR J.R. 1999. Crops and man, 2nd ed. American Society of Agronomy Crop Science of America Madison Wisconsin USA 284 pp.

HASSAN A.A, N.E. QURONFILAH, U.A. OBAJI, M.A. AL-RAYS, and M.S. WAFI 1991. Screening of domestic and wild C. Germplasm for resistance to yellow- stunting disorder in the United Arab Emirate. Cucurbit Genetic Cooperative Report 14: 98-101.

IGWEGBE E.C.K. 1983. Properties of a virus causing severe mosaic of Cucumeropsis edulis in Nigeria. Plant Dis. 67:315-317.

LEVETIN E.K. and C. MRNAHOII 2003. Plants and Society (3rd ed.) McGraw Hill, Dubuque, Lowe, U.S.A. 528 pp.

MAYNARD D. 2001. Watermelons: characteristics, production and marketing. ASHS Press.

MUSMADE A. M., and U.T. DESAI 2001. Cucumber and melon in handbook of vegetables science and technology: production, composition, storage and processing (eds.) Salunkhe, D. K. and Kadam, S. S.) Marcel Dekker, Inc, NY. Pp 25-34.

OBEN T.T., G.I. ATIRI, O. FAGBOLA, S.A. AKINBADE, P.O. OYIBO and P. LAVA 2007. Occurrence and distribution of viruses infecting fluted pumpkin (Telfairia occidentalis Hook F.) in Imo state Nigeria. Abstract in $10^{\text {th }}$ Plant virus Symposium, 15-19 October, ICRISAT, India.

OLANIYI J.O. and M.P. ODEDERE 2009. The effects of mineral $\mathrm{N}$ and compost fertilizers on the growth and yield and nutritional values of fluted pumpkin (Telfairia occidentalis) in south western Nigeria. Journal of animal and Plant Sciences 5: (1) 443-449.

OWOLABI A.T., F. RABENSTEIN, F. EHRIG, M. MAISS EDGAR, and H.J VETTEN 2012. Strains of Moroccan watermelon mosaic virus isolated from Lagenaria breviflovus and Coccinia barter in Calabar south eastern Nigeria. International Journal of Virology 8 (3): 258-270. 
OWOLADE A.T., F. RABENTEIN and F. EHRIG 2008. A strain papaya ringspot virus naturally infecting cucumber (Cucumis sativus L.) in Calabash, South Eastern Nigeria. Nigeria. J. Bot. 21: 97-108.

PROVVIDENTI R. 1996. Diseases caused by viruses. In: Compendium of Cucurbit Diseases (T.A. Zitter, D. L. Hopkins and C.F. Thomas, eds). St. Paul MN, USA, APS press; page 37-45.

RAO A.L.M. and A. VARMA 1984. Transmission studies with Cucumber green mottle mosaic virus. Phytopathology. Z. 109:325-331

RASSOLOV G. 2000. Cucumbers. Moscow: Ch. A. O and K0.30p.

SHOYINKA S.A, A.A. BRUNT, S. PHILLIPS, D.E. LESEMANN, G. THOTTAPPILLY, and R. LASTRA (1987). The occurrence, properties and affinities of Telfairia Mosaic Virus, a potyvirus prevalent in Telfairia (Cucurbitaceae) in South Western Nigeria. J. Phytopathol. 112: 13-24.

SUG-JU K. L. YONG-HWAN, C. MYOUNG-SOO, P. JIN-WOO, C. HONG SOO, L. GEUN-CHEOL and K. KOOK-HYUNG 2007. The incidence of virus diseases on melon in Jeonman Province during 2000-2002. Plant Pathology J. 23 (3): 215-218.

YARDIMCI N. and S. KORKMAZ 2004. Studies spread and identification of Zucchini yellow mosaic virus disease in the North-west Mediterranean region of Turkey by biologicalindexing and double stranded RNA analysis. Plant Pathology Journal3: 1-4. 